\title{
The Effect of Contextual Physics Teaching Materials Assisted by an Android-Based Virtual Lab to Improve Students' Conceptual Understanding During the COVID-19 Pandemic
}

\author{
Rahmatullah $^{1, *}$ Wipsar Sunu Bram Dwandaru ${ }^{2,}$ Heru Kuswanto ${ }^{2,}$ Ambrosius \\ Karanggulimu $^{1}$
}

\author{
${ }^{I}$ Master of Physics Education, Faculty of Mathematics and Natural Sciences, Universitas Negeri Yogyakarta, \\ Indonesia \\ ${ }^{2}$ Department of Physics Education, Faculty of Mathematics and Natural Sciences, Universitas Negeri \\ Yogyakarta, Indonesia \\ *Corresponding author. Email: rahmatullah.2019@student.uny.ac.id
}

\begin{abstract}
This is a quasi-experiment research with a quantitative approach. This research aimed to examine the effect of contextual physics teaching materials assisted by android-based laboratories in improving students' conceptual understanding. The sampling in this research were students in class XI IPA 4 (as a modelling class) and XI IPA 6 (as an implementation class) at SMAN 1 Muntilan. The sampling technique used is purposive sampling. The conclusion of this study is the use of contextual physics teaching materials with the help of an android-based virtual lab can improve students' conceptual understanding. These results prove that contextual physics teaching materials assisted by android-based virtual labs are effectively used to improve students' conceptual understanding. This finding is an effective alternative to learning in distance conditions and can also be used face-to-face.
\end{abstract}

Keywords: Teaching materials, Contextual physics, Virtual lab, Android, Conceptual understanding, COVID-19

\section{INTRODUCTION}

Learning during a pandemic presents a big challenge for teachers and students. Social distancing is a problem in the implementation of learning. Students are directed to study at their homes. Indonesian Ministry of Education and Culture encourages the implementation of the learning process to be carried out with a daring system. This is in accordance with the circular letter Number 03 of 2020 concerning the Prevention of Corona Disease Virus (Covid-19) in the Education Unit, and the Letter of the Secretary General of the Indonesian Minister of Education and Culture Number 35492/A.A5/HK/2020 concerning the Prevention of Covid-19. Teachers are required to be creative and innovative in addressing this problem so as to create effective and efficient learning.

The online learning that has been carried out so far has actually experienced problems in several schools. Physics is one of the subjects affected in its implementation. Before the pandemic occurred, physics had become a common problem for middle school students [1], [2]. Physics requires analytical skills in understanding every material (concept) that exists. Students have difficulty constructing existing concepts so that they are unable to master existing materials [3].

Incomplete understanding of physics concepts becomes a basic problem for students so that it leads to misconceptions [4]. Many students have wrong physics concepts even before starting learning [5]. 
Students often experience misunderstanding of physics concepts from both primary and secondary schools [6]. As a result, students' understanding of physics concepts is low.

Students' understanding of concepts looks very good if they are able to apply them in new situations [7]. Students must be able to understand physics and its role in real life so that they will be literate towards physics [8]. The importance of the role of physics in life makes the knowledge of concepts in physics need to be improved [9]. Therefore, learning physics needs to be linked to life so that the concepts that are obtained are inherent and able to minimize existing misconceptions.

One thing that needs to be carefully prepared during a pandemic is teaching materials. In fact, teaching materials are widely available in schools and communities. However, there are still many that are not in accordance with the principles of physics and are not yet integrated with technology [10]. This error in principle is one of the causes of misconceptions. A study has analyzed three commonly used physics textbooks [10]. The results show that the book contains a large element of knowledge. Meanwhile, for technology and society, there is very little investigation and interaction between science and thinking activities. The content of elements of knowledge that is too much and seems to contain text and similarities is another problem felt by students.

Teaching materials play an important role for teachers and students. Without teaching materials, the effectiveness of a lesson is hard to find [11]. Many tools are able to increase students' reading interest and understanding, such as contextual physics teaching materials. Contextual physics teaching materials can motivate students to read because the physics of concepts are associated with everyday life. Allchin [12] explained that students' interest in physics literacy will increase if they use interesting teaching materials. Students also find it easier to build physics concepts because they are packaged in real life applications.

The contextual teaching materials provided will look even more attractive if they serve with the help of the media. The use of media itself is rarely used by teachers in class. They think that the media is not optimal to implement and it takes a long time [13]. There are still few teachers who use technologybased media [14]. Whereas media has an important role to play in increasing the effectiveness of existing learning [15].
The social restrictions that occur prevent students from attending school. The laboratories available at the school are ultimately unused and students cannot carry out practicum activities. Finally, the cognitive abilities of students cannot be maximally developed. Even though there is a technology-assisted laboratory (virtual lab) that can be used as learning support. The weakness of collecting data / experiments is that it takes a lot of time and requires complete tools and facilities. This is not true with the help of virtual lab which can save time, cost, and risk [16].

This problem needs to be solved through a learning innovation. One form of innovation that can be provided is the provision of contextual physics teaching materials based on android and laboratory so that students' understanding of concepts can increase. This innovation offers an independent learning method with a control function carried out by teachers in online learning.

\section{RESEARCH METHOD}

This type of research is a quasi-experiment with a quantitative approach. This research aimed to examine the effect of contextual physics teaching materials assisted by android-based virtual labs to improve conceptual understanding student. The research method used was pre-experimental with a one group pretest-posttest research design [17].

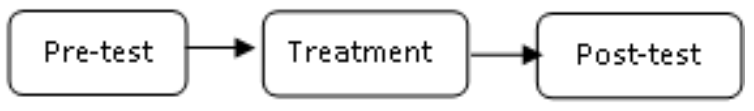

Figure 1 One group pre-test post-test

The subjects in this study were students in class XI IPA 4 and XI IPA 6 at SMAN 1 Muntilan in the 2019/2020 school year. Class XI IPA 4 is used as a modelling class and class XI IPA 6 is used as an implementation class. Subjects were determined by purposive sampling technique [18]. The research subjects consisted of 36 students of class XI IPA 4 and 36 students of class XI IPA 6. The material tested was limited to refraction and reflection.

The research was conducted in the modelling class and implementation class with the same learning process stages. The modelling class is filled by researchers while the implementation class is filled by teachers. The research process begins with: (1) conducting preliminary research (classroom observation); (2) formulating the research problem obtained from the preliminary research results; (3) making learning tools in the form of lesson plans (RPP), student worksheets and contextual physics 
teaching materials assisted by virtual labs; (4) create an assessment instrument; (5) validating learning tools and research instruments; and (6) revising learning tools and research instruments, (7) conducting classroom practices that have been used as research samples.

Data analysis used quantitative and qualitative analysis techniques. The data for the assessment of conceptual understanding on the pre-test and posttests generated by the two classes were then analyzed using descriptive statistics and sign test using the SPSS application. The N-gain test was also carried out to see how much improvement each sub-material was discussed. The $\mathrm{N}$-gain test is used to prevent the error of increasing the score from the students' initial and final test data, using equation [19]:

$$
\mathrm{N}-\text { gain }=\frac{\mathrm{S}_{\text {post }}-\mathrm{S}_{\text {pre }}}{\mathrm{S}_{\max }-\mathrm{S}_{\text {pre }}}
$$

Students' understanding of concepts is measured starting in the cognitive domains of applying (C3), analyzing (C4), evaluating (C5), and creating (C6). The test is given using the form of essay questions.

\section{RESULTS AND DISCUSSION}

Applications that have been developed are then tested in measuring students' conceptual understanding. The form of the android application can be seen in Figure 2 and 3. In the application there are several discussions of material on refraction and light reflection equipped with virtual-based applications and experiments. Students can learn and practice by themselves from their homes. In addition, this application is also equipped with exercises so that students can test their understanding of concepts.

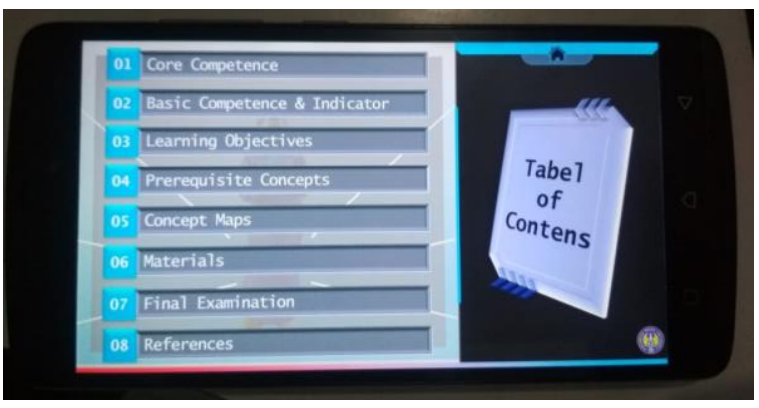

Figure 2 Table of contents

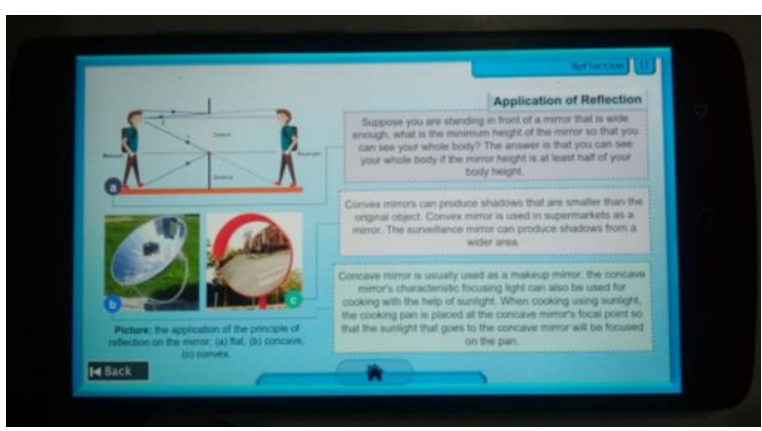

Figure 3 Material of contextual

The results of measuring students' conceptual understanding were obtained based on the scores of the pre-test and post-test scores. Measurement data were analyzed using descriptive statistics assisted by SPSS. The measurement results in the modelling class are shown in Table 1.

Table 1. Descriptive statistics of students' conceptual understanding in modeling class

\begin{tabular}{|l|l|l|l|}
\hline & Pretest & Posttest & $\begin{array}{l}\text { Valid N } \\
\text { (listwise) }\end{array}$ \\
\hline Subject & 36 & 36 & 36 \\
\hline Min & 22 & 78 & \\
\hline Max & 54 & 100 & \\
\hline Mean & 33.5 & 86.86 & \\
\hline $\begin{array}{l}\text { Std. } \\
\text { Deviation }\end{array}$ & 8.21 & 7.083 & \\
\hline
\end{tabular}

Table 1 shows the results of increasing students' conceptual understanding in the modelling class. This means that there are differences in conceptual understanding before and after learning by using contextual physics teaching materials assisted by virtual labs. In order to get more convincing results then the data were analyzed using the sign test and seeing the frequency of improvement. The number of students who experienced an increase can be seen in Table 2. The results of the sign test output can be seen in Table 3.

Table 2 Frequency of conceptual understanding in modelling class

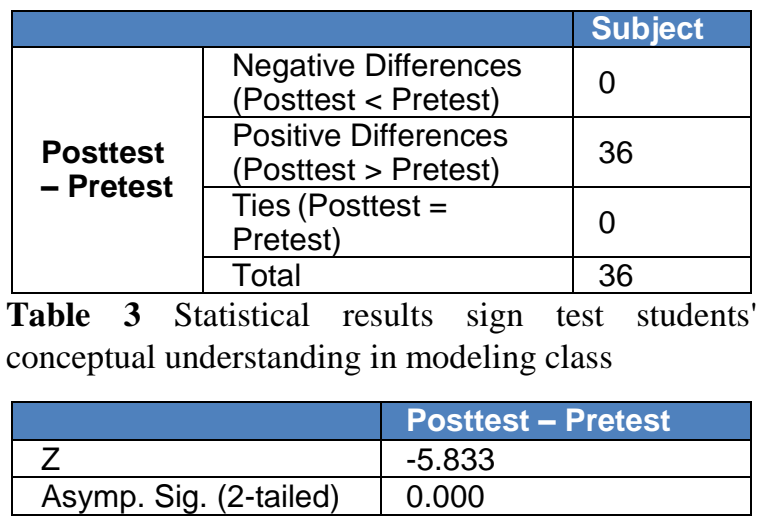


Table 3 shows that as many as 36 students had a post-test score that was higher than the pre-test. That is, students' understanding of concepts has increased as a whole. In addition, based on the results of statistical tests using the Sign Test, the sig value is obtained. by 0.00 . These results indicate that there is an increase in students' conceptual understanding after using contextual physics teaching materials assisted by an Android-based virtual lab in the modelling class. Learning looks active with the results of the work from practicum activities that students submit in a timely manner. A discussion and question and answer trip also took place with the direction of discussing physics and life. The concept of physics can be well embedded in the minds of students.

The results of increasing students' conceptual understanding can also be seen based on the $\mathrm{N}$-gain value obtained. The $\mathrm{N}$-gain test is used to check the increase in understanding of the concept in terms of the sub-material taught by each indicator. The indicators for achieving conceptual understanding are measured from the $\mathrm{C} 3$ to $\mathrm{C} 6$ domains. The material discussed in this study is light reflection and refraction.

An increase in students' conceptual understanding based on the sub-material discussed can be seen in Figure 4. This figure shows that in the model class there was a significant increase in the sub-material of refraction. This is influenced by the use of a virtual laboratory on refractive material. Meanwhile, the reflection material only adopts contextual material.

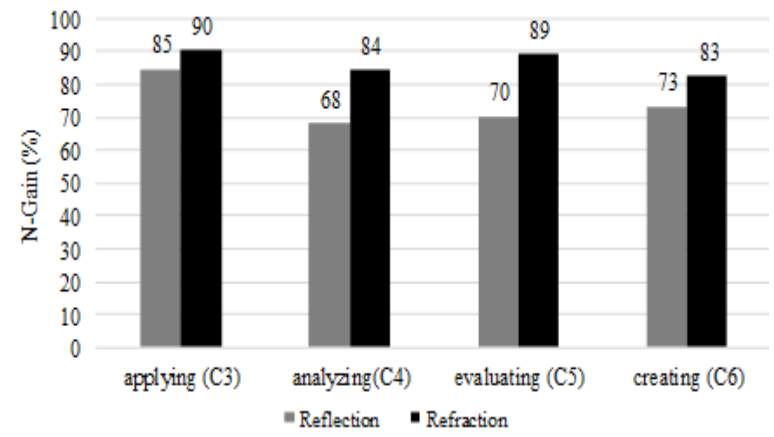

Figure 4 Comparison of $\mathrm{N}$-gain value in modelling class

Implementation research needs to be carried out in other classes to ensure an increase in understanding of the concepts that occur. Researchers conducted research in class XI IPA 6, namely as an implementation class. Learning in the classroom is carried out by the subject teacher. The results of the assessment of conceptual understanding at the pretest and post-tests are expected to have good results.
The analysis obtained in the implementation class based on the results of the pretest and posttest is shown in Table 4.

Table 4 Descriptive Statistics of Students' Concept Understanding in Implementation Class

\begin{tabular}{|l|l|l|l|}
\hline Indicator & Pretest & Posttest & $\begin{array}{l}\text { Valid N } \\
\text { (listwise) }\end{array}$ \\
\hline Subject & 36 & 36 & 36 \\
\hline Min & 35 & 72 & \\
\hline Max & 64 & 100 & \\
\hline Mean & 48.58 & 84.58 & \\
\hline $\begin{array}{l}\text { Std. } \\
\text { Deviation }\end{array}$ & 8.02274 & 7.88262 & \\
\hline
\end{tabular}

The mean pre-test score was 48.58 while the posttest average score was 84.58 which indicates an increase. So, it can be concluded that there are differences in understanding the concepts before and after learning with the innovations given. But to be more information, the data will be analysis by the Sign Test. The results of the Sign test output can be seen in the table below.

Table 5 Frequency of conceptual understanding in implementation class

\begin{tabular}{|l|l|l|}
\hline \multicolumn{2}{|c|}{} & Subject \\
\hline \multirow{3}{*}{$\begin{array}{l}\text { Posttest } \\
\text { Pretest }\end{array}$} & $\begin{array}{l}\text { Negative Differences } \\
\text { (Posttest < Pretest) }\end{array}$ & 0 \\
\cline { 2 - 3 } & $\begin{array}{l}\text { Positive Differences } \\
\text { (Posttest > Pretest) }\end{array}$ & 36 \\
\cline { 2 - 3 } & Ties (Posttest = Pretest) & 0 \\
\cline { 2 - 3 } & Total & 36 \\
\hline
\end{tabular}

Based on these data, it was found that 36 students had a higher post-test score than the pre-test. All students seemed to have increased their scores based on the results of the post-test pre-test they had done. That is, the understanding of the concept of implementation class students who apply learning using contextual physics teaching materials assisted by an android-based virtual lab has increased. The results of statistical tests can be seen in Table 6 .

Based on statistical tests using the Sign Test obtained sig. of 0.00 . Because sig. $<0.05$, so there was an increase in students' conceptual understanding after using contextual physics teaching materials assisted by android-based virtual labs in the implementation class.

Table 6 Statistical results sign test students' conceptual understanding in implementation class

\begin{tabular}{|l|l|}
\hline & Posttest - Pretest \\
\hline Z & -5.833 \\
\hline Asymp. Sig. (2-tailed) & 0.000 \\
\hline The increase in students conceptual
\end{tabular}
understanding based on the sub-material discussed can be seen in Figure 5. This figure shows that in the 
implementation class there was a significant increase in the sub-material of refraction. The results obtained are similar to the results in the modelling class. However, in the evaluating realm, there is no difference in increase between reflection and refraction sub-material.

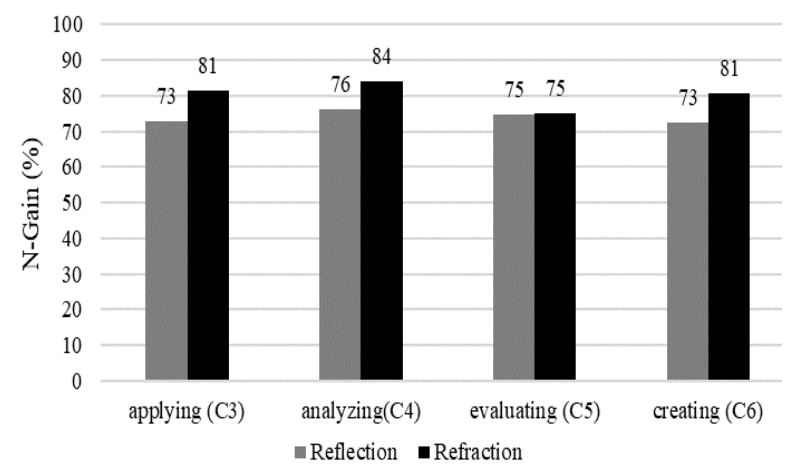

Figure 5 Comparison of $\mathrm{N}$-gain value in implementation class

Research is running smoothly even in the midst of the Covid-19 pandemic. During learning, students get full control from teachers and researchers with the help of the WhatsApp (WA) application. Through this application, learning steps are applied starting from preliminary activities, core activities, and closing activities.

Preliminary activities begin with the attendance of students. Attendance is carried out using voice notes found in the WhatsApp application. The reason for using this feature is to find out the condition of the students themselves through the given voice control. They will mention each other's name, presence, and physical state. Before continuing learning, students must ensure that the application is actually installed on their respective Androids. After everything is ready, the researcher and teacher then direct to read the instructions for use in the given application. One of the advantages of this Android-based teaching material is that it can be used remotely so that students' learning activities can be done anytime and anywhere. Learning media using mobile apps is promising [20].

The use of Android as a learning medium is a 21st century learning application. The use of android has the potential to improve student learning outcomes in the cognitive realm [21]. The smartphone used has the ability to transform learning experiences for students. Learning becomes more interesting and fun [22].
The android-based teaching materials provided have the same content components as the usual textbooks. This teaching material contains several elements including the front page, instructions for use, preface, table of contents, material, student worksheet, practice questions, bibliography, and author profile. The differences that are owned are the concepts developed in the material associated with examples that occur in everyday life.

Based on the results of the students' responses, this teaching material makes learning easier. Learning that is equipped with musical instruments provides comfort in their learning. The appearance is quite attractive with a material design that is concise, solid and clear. The material which contains implementation in everyday life makes the concept well embedded. The results provide an increase in students' conceptual understanding.

Contextual physics teaching materials have a positive influence on students' conceptual understanding [23], [24]. The difference in learning outcomes between the use of a web-based contextual physics-based module with contextual learning is that there are differences in results [25]. Understanding the concept of web-based learning with contextual physics modules has a better understanding of concepts than conventional learning.

This teaching material is equipped with a virtual laboratory so that students can do practical work from home without having to go to school. The experiment carried out was the refraction of light (Snellius's law). The teacher provides directions through the worksheet while monitoring practicum activities. At the end of the experiment, students made their own practical report as a form of process skills training. Each student shows the results of their practicum followed by discussion activities. In the application there is an experimental question section. This question is intended to test students' understanding during practice/learning. The results of students' answers were immediately sent via email to researchers.

The virtual laboratory is well designed using the PhET Simulation platform. The use of virtual laboratories has a positive effect on students' conceptual understanding [26]. This study is supported by previous research [27] that learning using a combination of real experiments and virtual experiments improves concept understanding more than just real experiments. Other studies have also found that the use of virtual labs in learning can foster better understanding in students [28]. 


\section{CONCLUSION}

The use of android during the pandemic has a positive impact on student learning. Contextual physics teaching materials with the help of a virtual lab can be packaged into one platform (android) to facilitate distance learning activities. The virtual lab is applied after the learning material is given so that the knowledge gained can be constructed. The results obtained are the increased understanding of concepts in students. This finding is an effective alternative to learning in distance conditions and can also be used face-to-face.

\section{REFERENCES}

[1] R.M.D. Guido, Attitude and Motivation toward Learning Physics, International Journal of Engineering Research \& Technology 2(11) (2013) 2087-2093.

[2] A. Ohle, W.J. Boone, H.E. Fischer, Investigating The Impact of Teachers' Physics CK On Students Outcomes, International Journal of Science and Mathematics Education 13(6) (2015) 1211-1233. DOI: https://doi.org/10.1007/s10763-014-9547-8

[3] Rahmatullah, Suparno, The Development of Experimental Absorption Based on ArduinoUno and Labview on Light Radiation by Colourful Surface, Jurnal Pendidikan Fisika Indonesia 16(1) (2020) 41-46. DOI: https://doi.org/10.15294/jpfi.v16i1.23596

[4] K.L. Ting, N.M. Siew, Effects of Outdoor School Ground Lessons on Students' Science Process Skills and Scientific Curiosity, Journal of Education and Learning 3(4) (2014) 96-107. DOI: https://doi.org/10.5539/jel.v3n4p96

[5] A.J. Kola, Investigating The Conceptual Understanding of Physics Through an Interactive Lecture-Engagement, Cumhuriyet International Journal of Education-CIJE 6(1) (2017) 82-96.

[6] J.L. Docktor, J.P. Mestre, Synthesis of Discipline-Based Education Research in Physics, Physical Review Special TopicsPhysics Education Research 10(2) (2014) 1-58. DOI:

https://doi.org/10.1103/PhysRevSTPER.10.0201 19

[7] S. Saleh, A. Mazlan, The Effects of Brain-Based Teaching with I-Think Maps and Brain Gym
Approach towards Physics Understanding, Jurnal Pendidikan IPA Indonesia 8(1) (2019) 1221. DOI: https://doi.org/10.15294/jpii.v8i1.16022

[8] P. Oon, R. Subramaniam, On The Declining Interest in Physics Among Students From The Perspective of Teachers, International Journal of Science Education 33 (5) (2011) 727-746. DOI: https://doi.org/10.1080/09500693.2010.500338

[9] B.K. Prahani, I. Limatahu, W.W. Soegimin, L. Yuanita, M. Nur, Effectiveness of Physics Learning Material Through Guided Inquiry Model to Improve Student's Problem-Solving Skills Based on Multiple Representation, International Journal of Education and Research 4(12) (2016) 231-242.

[10] N. Maturradiyah, A. Rusilowati, Analisis Buku Ajar Fisika SMA Kelas XII di Kabupaten Pati Berdasarkan Muatan Literasi Sains, Unnes Physics Education Journal 4(1) (2015) 16-20. DOI: https://doi.org/10.15294/upej.v4i1.4731

[11] S. Perwitasari, W. Wahjoedi, S. Akbar, Pengembangan Bahan Ajar Tematik Berbasis Kontekstual, Jurnal Pendidikan Teori, Penelitian dan Pengembangan 3(3) (2018) 278-285. DOI: https://doi.org/10.17977/jptpp.v3i3.10623

[12] D. Allchin, From Science Studies to Scientific Literacy: A View from the Classroom, Science and Education 23(9) (2014) 1911-1932. DOI: https://doi.org/10.1007/s11191-013-9672-8

[13] S.J. Cooley, V.E. Burns, J. Cumming, The Role of Outdoor Adventure Education in Facilitating Groupwork in Higher Education, Higher Education 69 (2014) 567-582. DOI: https://doi.org/10.1007/s10734-014-9791-4

[14] V.D. Beemt, I. Diepstraten, Teacher Perspectives on ICT: A Learning Ecology Approach, Computers and Education 92 (2016) 161-170.

DOI: https://doi.org/10.1016/j.compedu.2015.10.017

[15] R.W.H. Lau, N.Y. Yen, F. Li, B. Wah, Recent Development in Multimedia E-Learning Technologies, World Wide Web 17(2) (2014) 189-198. DOI: https://doi.org/10.1007/s11280013-0206-8

[16] I. Ismail, A. Permanasari, W. Setiawan, Efektivitas Virtual Lab Berbasis STEM dalam Meningkatkan Literasi Sains Siswa dengan Perbedaan Gender, Jurnal Inovasi Pendidikan 
IPA 2(2) (2016) 190-201. DOI: https://doi.org/10.21831/jipi.v2i2.8570

[17] E. DePoy, L.N. Gitlin, Introduction to Research Elsevier, 2011.

[18] Sugiyono, Combination Research Method: Mixed Method, Alfabeta, 2013.

[19] K.K. Cheng, B.A. Thacker, R.L. Cardenas, C. Crouch, Using An Online Homework System Enhances Students' Learning of Physics Concepts in An Introductory Physics Course, American Journal of Physics 72(11) (2004) 1447-1453.

DOI: https://doi.org/10.1119/1.1768555

[20] I.R. Lubis, J. Ikhsan, Pengembangan Media Pembelajaran IPA Berbasis Android untuk Meningkatkan Motivasi Belajar dan Prestasi Kognitif Siswa SMA, Jurnal Inovasi Pendidikan IPA 1(2) (2015) 191-201. DOI: https://doi.org/10.21831/jipi.v1i2.7504

[21] K.K. Jabbour, An Analysis of The Effect of Mobile Learning on Lebanese Higher Education, Informatics in Education 13(1) (2014) 1-15.

[22] A.A. Sakat, M.Z.M. Zin, R. Muhamad, A. Ahmad, N.A. Ahmad, M.A. Kasmo, Educational technology media method in teaching and learning progress, American Journal of Applied Sciences 9(6) (2012) 874-888. DOI: https://doi.org/10.3844/ajassp.2012.874.878

[23] W. Oktaviani, Gunawan, Sutrio, Pengembangan Bahan Ajar Fisika Kontekstual untuk Meningkatkan Pemahaman Konsep Siswa, Jurnal Pendidikan Fisika dan Teknologi 3(1) (2018) 1-7. DOI: http://dx.doi.org/10.29303/jpft.v3i1.320

[24] M. Satriawan, R. Rosmiati, Pengembangan Bahan Ajar Fisika Berbasis Kontekstual dengan Mengintegrasikan Kearifan Lokal untuk Meningkatkan Pemahaman Konsep Fisika pada Mahasiswa, Jurnal Penelitian Pendidikan Sains 6(1) (2016) 1212-1217. DOI: http://dx.doi.org/10.26740/jpps.v6n1.p1212$\underline{1217}$

[25] R. Sujanem, Pengembangan Modul Fisika Kontekstual Interaktif Berbasis Web untuk Meningkatkan Pemahaman Konsep dan Hasil Belajar Fisika Siswa SMA di Singaraja, Jurnal Nasional Pendidikan Teknik Informatika 1(2) (2012) 103-117. DOI: http://dx.doi.org/10.23887/janapati.v1i2.9825
[26] Gunawan, N. Nisrina, N.M.Y. Suranti, L. Herayanti, Rahmatiah, Virtual laboratory to improve students' conceptual understanding in physics learning, in: Journal of Physics: Conference Series, vol. 1108, IOP Publishing, Bristol, 2018, pp. 1-7. DOI: https://doi.org/10.1088/1742$\underline{6596 / 1108 / 1 / 012049}$

[27] Z. Zacharia, O.R. Anderson, The Effects of An Interactive Computer-Based Simulation Prior To Performing A Laboratory Inquiry Based Experiment on Students' Conceptual Understanding of Physics, American Journal of Physics 71(6) (2003) 618-629. DOI: https://doi.org/10.1119/1.1566427

[28] N.R. Herga, B. Cagran, D. Dinevski, Virtual Laboratory in The Role of Dynamic Visualisation for Better Understanding of Chemistry in Primary School. Eurasia Journal of Mathematics, Science and Technology Education 12(3) (2016) 593-608. DOI: https://doi.org/10.12973/eurasia.2016.1224a 